\title{
Legal Certainty Against Halal Certification Of Investment Fund
}

\author{
Shohibul Khoir ${ }^{1}$, Andre Meiryandy Sugesty ${ }^{2}$, Shandy Aldo Hamonangan ${ }^{3}$ \\ (alapolakhoir@gmail.com ${ }^{1}$, myandreasi@gmail.com², shandyaldo11@gmail.com ${ }^{3}$ ) \\ Faculty of Law, Universitas Airlangga ${ }^{1,2,3}$
}

\begin{abstract}
The title of this study is " Legal certainty against halal certification of investment fund". Therefore, the legal issue discussed in this study is to analyze the legal certainty of halal certification on mutual fund investments. This study used two types of approach, namely statue approach, and conceptual approach. Statue approach is carried out by identifying and discussing regulations related to halal certification of mutual fund investments. On the other hand, the conceptual approach is made by looking at the values and concepts associated with halal certification of mutual fund investments. In regards to the legal issues in the halal certification of mutual fund investments and based on the fatwa from National Sharia Board of Indonesian Ulama Council (Dewan Syariah Nasional Majelis Ulama Indonesia, abbreviated as DSN MUI) number 20/DSN-MUI/IV/2001, mutual fund investment is known to have legal certainty. Mutual fund investments have contracts, namely wakalah contract, and mudharabah contract. As long as the mutual fund investments do not contradictory with the prevailing law, halal certification will obtain legal certainty.
\end{abstract}

Keywords: Legal certainty, halal certification, mutual fund investment

\section{Introduction}

The capital market is a market for various financial instruments or long-term securities that can be traded either in the form of debt or capital. Many industries and companies use capital market institutions as a medium to absorb investment and to strengthen their financial position. A capital market is an effective means of obtaining funds and is used as investment funding by collecting funds from the community and channeling it to productive sectors.

With the development of the capital market, the alternative investment for investors is now no longer limited to "real assets" and savings but also in the form of stocks, bonds, and other securities. By buying shares, investors expect to receive dividends every year as well as capital gains when the shares are resold. With the investments, investors are also expected to risk losses that are directly proportional to the profits obtained.

Mutual funds is an alternative investment for investors, especially small investors, and investors who do not have much time and expertise to calculate the risks of their investments. Mutual funds are designed as a means to raise funds from people who have capital and the desire to invest but have limited time and knowledge. Nowadays, society is increasingly aware of the financial markets and understand the valuation and control of investment risk. By that, the society will be more courageous to enter riskier areas. By joining the capital market, the capital community enters a more challenging area. It will encourage the use of analyzing capabilities that investors have and at the same time, promoting better returns. 
Sharia principles in the capital market are the principles of Islamic law which regulate capital market activities based on the Fatwa of the National Sharia Board of Indonesian Ulama Council (Dewan Syariah Nasional Majelis Ulama Indonesia, abbreviated as DSN MUI), both in the form of DSN-MUI fatwas stipulated in the Capital Market Supervisory Agency (Badan Pengawas Pasar Modal, abbreviated as BAPEPAM) and Financial Institutions (Lembaga Keuangan, abbreviated as LK) as well as DSN-MUI fatwas which have been issued prior to the existence of this regulation as long as the fatwas suit the Islamic principles. Besides simplicity, investors do not need to analyze or monitor their investment development because it has been handled by a professional investment manager. Not only that, the security of mutual funds is a mixed investment that combines shares and liabilities in one product.

Generally saying, mutual funds are a phenomenon of how a service is given to investors who want to participate in the capital market but do not want to be preoccupied with all kinds of the complicated procedures, administrations, and analysis. The benefits obtained by investors if investing in mutual funds are first if they do not have sufficient funds, they can diversify the investments in securities as to minimize the risk. Secondly, mutual funds ease the investors to invest in the capital market and last but not least, time efficiency.

By investing in mutual funds, the funds will be managed by professional investment managers so that investors do not have to monitor the performance of their investments. In its development, along with the rise of financial institutions that use Islamic principles like banking, it turns out that mutual funds also affect other financial institutions, for example, Islamic principles-based insurance and Islamic principles-based capital markets. One of the institutions that play an important role in capital market activities is a mutual fund company. To date, besides conventional mutual funds, there are also mutual funds that are managed based on Islamic principles.

Islamic investment funds are a mixed investment facility that combines Islamic stocks and bonds in a single product that is managed by an investment manager. At present, Islamic investment funds is an attractive investment for people who want to invest by sharia principles. Islamic investment funds is an investment alternative that only places funds to debtors who do not want to violate the Islamic law in the fundamentals and operational means of the company based on the fatwa of the MUI DSN number 20/DSN-MUI/IV/2001.

Also, it has been set by the government that a halal certificate must be possessed by the investigation product so that in improving the economy of the government, it is certain that there is no doubt for people to invest. The obligation to perform halal certification is regulated in article 29 of Law number 33 of 2014 concerning Halal Products Guarantee. This article mentions several conditions that must be met if the business actor wants to get halal certification.

Along with the application of halal certification on investment, it raises a new problem in the form of time efficiency. If the regulation is applied, the investment that does not need to take much time will have to go through a longer process. Based on the background as described above, a study entitled the Legal Certainty of Halal Certification on Mutual Fund Investments is carried out.

The objectives of this research are (a) to find out and analyze the legal certainty of halal certification for an Islamic investment fund, and (b) To find out and analyze the legal protection of investors in Islamic investment funds 


\section{Methods}

The method of the research used in this study is library research conducted with secondary data in the form of primary legal material. Whereas, the data collection is done by library research with a legal approach and conceptual approach. The data obtained from the results of library research are systematically and scientifically analyzed to answer the problem statement.

\section{Discussion}

\subsection{Legal certainty of halal certification on Islamic investment fund}

Mutual funds are mutual funds operated by an investment company who collects money from shareholders and invests it into shares, bond, option, commodities, or money market securities. This kind of mutual funds offers the advantages of diversification and professional management to investors. For these services, they usually charge a management fee, usually $1 \%$ or less of assets per year.

With the issuance of the fatwa from National Sharia Board of Indonesian Ulama Council (DSN MUI) number 20/DSN-MUI/IV/2001 concerning the Guidelines for the Implementation of Islamic Investment Funds, each person who wants to be investor have the legal certainty in terms of Islamic law. Thus, every person or group will not hesitate in investing their money into the business they desired. With the existence of halal certification from Indonesian Ulama Council (MUI) in concern with mutual fund investments that do not conflict with other laws and regulations, it is apparent that investors have evident legal power and legal certainty.

Akad or a contract (bond, decision, or reinforcement), an agreement, or a transaction can be interpreted as a commitment framed with Islamic values. In terms of Fiqh (Islamic jurisprudence), Akad means something that is determined by someone to carry out, whether it arises from one party or two parties. Specifically, akad means the relationship between ijab and qabul (ownership beneficiaries statement) in the scope of Islamic law and value [1].

Securities that do not conflict with Islamic principles are issued using Islamic securities issuance contracts in the capital market as regulated in BAPEPAM and LK regulations number IX.A.14. Islamic securities issuance contracts in capital market consist of [2]:

a. Ijarah, an agreement ( $a k a d$ ) in which a party that owns goods or services (the lessor or service provider) promises to the tenant or service user to give the right to use or utilize the items and/or provide services owned by the lessor or service provider in a particular time with payment and/or wages (ujrah) without being followed by the transfer of rights to the ownership of Ijarah objects.

b. Kafalah, an agreement ( $a k a d)$ in which the guarantor ( kafiil) promises to provide guarantees to guaranteed parties (makfuul 'anhu/ashil/debtor) to fulfill the obligations of the guaranteed parties to other parties (makfuul lahu/creditor).

c. Mudharabah (qiradh), is an agreement (akad) in which the provider (shahib al-mal) promises to the business manager (mudharib) to give up the capital and the manager (mudharib) promises to manage the capital.

d. Wakalah, an agreement ( $a k a d)$ where the party that gives power of attorney (muwakkil) gives power to the party that receives a power of attorney (wakil) to take certain actions.

The mechanisms of mutual fund investments are similar to profit sharing investments. Investors and investment managers "joint venture" to invest in various investment products that 
require significant capital while the decision to invest is entirely held by a more expert and experienced investment manager. Furthermore, the results of the investment profits are shared among investors and investment managers by the proportion of capital owned. The Islamic investment fund is an intermediary facility that helps surplus units to place funds to be invested. This is intended to meet the needs of groups of investors who want to obtain investment income from clean sources and methods that can be religiously accounted for in line with Islamic principles. Therefore, the fulfillment of Islamic values is the ultimate goal [3].

At least, there are two terms in Al Qur'an that related to an agreement, namely al-aqdu (contract or $a k a d$ ) and $a l$-'ahdu (promise). Linguistically, what is meant by an agreement is a bond or binding. It is said that a bond means to collect two ends of a rope and tie one of the ends to the other until they are joined together and become a single string [4]. According to Fathurrahman Djamil, the term al-aqduini can be interpreted as a verbintenis term in the Civil Code [4]. While on the other hand, the term $a l-a h d u$ can be equated with the term agreement or overeenkomst, which is a statement from someone to do or not do something that is not related to other people [4].

The fatwa of DSN-MUI number 20/DSN-MUI/IV/2000 on Guidelines for Islamic Investment Fund Implementation stated that:

a. Conventional mutual fund activities still contain many elements that are not by Islamic principles both in terms of contracts, investment objectives, technical transactions, income, and profitability.

b. Investments can only be made on financial instruments that are by Islamic principles which include shares through public offerings and dividends based on the level of business profit - the placement of Islamic bank deposits and debt securities are by Islamic principles.

c. The business type of the issuer must be by Islamic principles such as not involved in the gambling business, riba businesses, haram food, and beverages production and distribution businesses, as well as services that damage the morale of the society.

d. The issuers are declared to be not fit to invest in Islamic investment funds if the structure of debt to capital relies heavily on debt. In essence, it includes financing that contains the elements of riba. The issuers must have a debt to equity ratio of more than $82 \%$ (45\% debt, $55 \%$ capital).

e. The operational mechanism of Islamic investment funds consists of a contract between investment managers and investment users as well as mudharabah between investment managers and investment users [5].

f. The operational sensitivity of Islamic investment funds consists of wakalah contracts between investment managers and investment users as well as mudharabah between investment managers and investment users. The characteristics of mudharabah are as follows (a) The distribution of profits between investors (Shahibul al-mall) represented by the Investment Manager and investment users is based on the proportion agreed upon by both parties through the Investment Manager as a representative, and there is no guarantee of certain investment returns to investors. (b) Investors only bear the risk of the funds that have been given (c) The Investment Manager as a representative does not bear the risk of bankruptcy for the investment he/she has made as long as it is not due to his negligence (gross negligence/tafrith).

g. The investment income that can be received by the Islamic investment fund is: (a) From the shares, it can be in the form The dividend (a profit-sharing given from the profits generated by the issuer either in cash or in the form of shares), Right (the right to order more upstream securities provided by the issuer), and Capital gain (the profit derived from buying and selling shares in the capital market), (b) From the bonds that are in accordance with Islamic 
principles of profit sharing system, it is received periodically from the issuer's profits, (c) From Money Market Securities that are in accordance with Islamic principles of profit sharing system, issuers receive it, and (d) From deposits, it can be in the form of profit sharing received from Islamic banks [1].

\subsection{Legal protection of investors in Islamic investment funds}

According to R. La Porta in the Journal of Financial Economics, the form of legal protection provided by a country has two properties, namely prohibited and sanction [6]. The most apparent form of legal protection is the existence of law enforcement institutions such as courts, police, and other institutions (non-litigation).

Soedjono Dirdjosisworo said that the notion of law could be seen from eight meanings: law in the sense of ruler, law in the sense of officers, law in the sense of action, law in the sense of system rules, law in the sense of value, law in the sense of law order, law in the sense of law sciences, and law in the sense of legal discipline. Some legal meanings from various perspectives expressed by Soedjono Dirdjosisworo illustrate that the law is not merely a written legislation and law enforcement officials as it has been understood by the general public who do not know about the law. Law also covers things that have been fulfilled in community relations [7].

One of the functions of a law is to protect human interests so that a law must be enforced to make human interests protected. In this case, Law number 8 of 1995 concerning the Capital Market is one of the sources of law [8]. In correlation with the legal protection of these investors, Marulak Pardede, as quoted by Hermansyah, believed that in the Indonesian capital market system, legal protection for investors could be done in 2 ways, namely:

a. Implicit Deposit Protection is the protection generated by the supervision and guidance produced by the supervision and guidance of active capital markets which could avoid bankruptcy of the capital market. This protection is obtained through (a) Legislation in the field of capital markets, (b) Protection produced by effective supervision and guidance from Bapepam, (c) Business by the principle of prudence, and (d) Information that is transparent to investors.

b. Explicit Deposit Protection is protection through the establishment of an institution that guarantees the investment community. Therefore, if the fund fails, the agency is the party who will replace the public funds invested [8].

One of the means to protect Mutual Fund Investors is Law number 8 of 1995 concerning the Capital Market. There are restrictions, limitations, and sanctions for those who violate the law. These restrictions include: (a) Mutual Funds are prohibited from receiving and or provide loans directly, (b) Mutual Funds are prohibited from buying shares or other Investment Participation Units, and (c) Investment restrictions through the mutual funds are regulated by Bapepam LK [7], [8].

Legal protection for Mutual Fund Investors is primarily based on the responsibilities of the Investment Manager and Custodian Bank as the manager and the depositors of Mutual Fund as well as portfolio securities administrator. One form of legal protection for Investors or Holders of Participation Units is licensing. It is written in Article 5 of the Law number 8 of 1995 to give the authority to Bapepam LK whereas, to date, the Financial Services Authority (Otoritas Jasa Keuangan, abbreviated as (OJK) is permitted to give permission to the Securities Company and individual licenses to Investment Manager as well as approval for the Custodian Bank. To get permission and approval, there are requirements that must be met from Bapepam LK and OJK. The licensing and approval given by Bapepam LK and OJK is a protection for the Unit Holder 
because the parties of Investment Fund will be accounted for their actions and professionalism [9].

Investors, especially professional investors, and institutional investors, always actively collect for various information and use it to understand the stock prices offered in primary and secondary markets. The information gathered usually contains material facts [10].

a. Bapepam Regulation number IV.A.3 point 1 letter $(\mathrm{g})$ stated that the Mutual Fund in the form of a company that has obtained a business license must fulfill the following conditions: Investment Managers must submit all reports, material records, and other relevant information to the directors and must provide other information relating to the management of mutual funds requested by directors to assess the mutual fund management contracts; Legal protection provided for the Company's Mutual Fund Investors must be in accordance with the rules and regulations in:

b. Bapepam Regulation number IV.A.3 point 11 showed that the Investment Managers must maintain all essential records relating to financial statements and management of mutual funds as determined by the Capital Market Supervisory Agency;

c. Bapepam Regulation number IV.A.5 point 4 explained that the Custodian Bank must administer the securities and funds from the Mutual Fund and provide safekeeping services for securities and other assets related to securities and other services including dividend, interest, and other rights, as well as completing securities transactions;

d. Bapepam Regulation number IV.A.5 point 7 said that the Custodian Bank is obliged to do the registration, change in the ownership of securities, and distribute the rights related to the shares of Mutual Fund [9].

The form of legal protection provided by OJK to investors is preventive and repressive in the form of precaution and sanctions considering that the OJK must regulate and supervise the financial services sector. Article 28 Law number 21 of 2011 in concern to OJK provides legal protection to prevent investor losses, among others:

a. Provide information and education to the community about the characteristics of the financial sector including its services and products;

b. Ask the Financial Services Agency to stop its activities if the activity has the potential to harm investors/consumers; and

c. Other actions deemed necessary by the prevailing regulations in the financial services sector [6].

Other forms of legal protection provided are repressive if there is a dispute between investors and financial service industry companies. Henceforth, the OJK has the authority to carry out legal defense for the interests of investors and the public. The legal defense involves ordering financial service company to resolve complaints made by consumers who feel disadvantaged by:

a. Taking an order or specific actions to the Financial Services Institution to resolve consumer complaints that have been harmed by the Financial Services Institution;

b. Filing a lawsuit to recover the assets of the party who are harmed by other party, either those under the control of the party who cause the loss or under the control of another party who have wrong motives; and/or to obtain compensation from the party who causes losses to the consumers or the Financial Services Institution as a result of law and regulation violations in the financial services sector [9]. 


\section{Conclusion}

The issuance of the fatwa from National Sharia Board of Indonesian Ulama Council (Dewan Syariah Nasional Majelis Ulama Indonesia, abbreviated as DSN MUI) number 20/DSN-MUI/IV/2001 concerning the Guidelines for the Implementation of Islamic Investment Funds, each person who wants to become investors have the legal certainty in terms of Islamic principles. Therefore, every person or group will not hesitate in investing their money into a business they desired. With the existence of halal certification from the Indonesian Ulama Council (MUI) on mutual fund investments that do not conflict with other laws and regulations, it is evident that investors have evident legal strength and legal certainty.

Legal protection, in this case, is emphasized in the implicit deposit protection by tightening the bank regulation and supervision who act as agents of mutual fund so that they apply the prudential banking principles that are based on the Capital Market Law. Whereas, explicit deposit protection for customers is not given enough attention because Mutual Funds are not bank products. Mutual funds are capital market products that are not guaranteed by the bank and are not included in the object of deposit guarantee program if the business license is revoked. As stated in the Mutual Fund sale and purchase contracts, if the banks violate the applicable provisions in the transaction, the investor may sue the bank for the cancellation of the contracts along with compensation for all costs, interest, and losses, either through court or outside court. Meanwhile, to the Investment Manager, investors can illegally file a lawsuit.

\section{References}

[1] A. W. Nafis, 'Akad-akad di Dalam Pasar Modal Syariah', Iqtishoduna J. Ekon. Islam, vol. 5, no. 1, pp. 66-86, 2015.

[2] A. Nurlita, 'Investasi di Pasar Modal Syariah Dalam Kajian Islam', J. Penelit. Sos. Keagamaaneagamaan, vol. 17, no. 1, pp. 12-13, 2014.

[3] I. Achsien, Investasi Syariah Di Pasar Modal: Menggagas Konsep dan Praktek Manajemen Portofolio Syariah. Jakarta: Gramedia, 2000.

[4] G. Dewi, Wirdyaningsih, and Y. S. Barlinti, Hukum Perikatan Islam Indonesia. JAkarta: Prenada Media Grup, 2018.

[5] Majelis Ulama Indonesia, Himpunan Fatwa Majelis Ulama Indoneia Sejak 1975. Jakarta: Sekertariat Majelis Ulama Indoneisa, 2011.

[6] H. H. Dimyati, 'Perlindungan Hukum Bagi Investor Dalam Pasar Modal', J. Cita Huk., vol. 2, no. 2, pp. 341-356, 2014.

[7] S. Dirdjosisworo, Pengantar Ilmu Hukum. Jakarta: Raja Grafindo Persada, 2008.

[8] T. Kurniadihardja and S. Mulyani, 'Tinjauan Yuridis Tentang Reksa Dana Syariah Sebagai Alternatif Investasi bagi Investor', Lex Jurnalica, vol. 8, no. 1, pp. 56-72, 2010.

[9] M. R. Ridha, B. Nasution, and M. Siregar, 'Peranan Reksadana Syariah Dalam Peningkatkan Investasi di Indonesia', TRANSPARENCY, J. Huk. Ekon., vol. 2, no. 2, pp. 1-11, 2013.

[10] S. Adrian, Tax Law. Jakarta: Sinar Grafika, 2013. 